\title{
Prasības nodrošinājuma problemātika
}

\author{
Mg. iur. Andrejs Gvozdevičs \\ Rìgas Stradina universitāte, Doktorantūras nodaḷa, \\ Juridisko zinātñu programma, Latvija \\ 040504@rsu.edu.lv
}

\section{Kopsavilkums}

Rakstā tiek apskatīti prasības nodrošinājuma tiesiskā regulējuma problēmjautājumi, jo pēdējos gados būtiski prasības nodrošinājuma tiesiskā regulējuma uzlabojumi netika veikti, samazinot šā tiesību institūta efektivitāti. Tiek aktualizētas prasības nodrošinājuma tiesiskā regulējuma un tā piemērošanas problēmas, lai rosinātu diskusijas par to risināšanu un veicinātu prasības nodrošinājuma civilprocesa ekonomiju, efektivitāti un iedarbīgumu.

Atslēgvārdi: prasības nodrošinājums, civilprocess, maksātnespējas process, procesuālā ekonomija.

\section{levads}

Pirms vairākiem gadiem Latvijā notika diskusijas par prasības nodrošinājuma institūtu. Tās vainagojās ar 2011. gada 4. augusta Civilprocesa likuma grozìjumiem, kas stājās spēkā 2011. gada 1. oktobrī [1]. Šajos likuma grozijumos noteikta nepieciešamība veikt prasības pirmšḳietamā (prima facie) formālā juridiskā pamatojuma izvērtējumu, kas ir viens no prasības nodrošinājuma pieteikuma izvērtēšanas kritērijiem. 2015. gadā Latvijas Republikas Augstākā tiesa izveidoja tiesu prakses apkopojumu “Tiesu prakse prasības nodrošināšanas lietās" [13], un judikatūrai pēc šeit minētajiem Civilprocesa likuma grozijjumiem tika pievienoti daži Augstākās tiesas nolēmumi:

- Latvijas Republikas Augstākās tiesas Senāta Civillietu departamenta 2012. gada 20. jūnija lēmums lietā Nr. SKC-1644/2012 [10];

- Latvijas Republikas Augstākās tiesas Senāta Civillietu departamenta 2013. gada 24. aprīḷa lēmums lietā Nr. SKC-1654/2013 [11];

- Latvijas Republikas Augstākās tiesas Senāta Civillietu departamenta 2013. gada 4. decembra lēmums lietā Nr. SKC-2021/2013 [12]; 
- Latvijas Republikas Augstākās tiesas Civillietu departamenta 2014. gada 29. decembra lēmums lietā Nr. SKC-3133/2014 [6];

- Latvijas Republikas Augstākās tiesas Civillietu departamenta 2017. gada 12. janvāra spriedums lietā Nr. C37105312 SKC-5/2017 [7];

- Latvijas Republikas Augstākās tiesas Civillietu departamenta 2017. gada 17. oktobra lēmums lietā Nr. C30316415, SKC-1587/2017 [8].

Kopš 2015. gada būtiski grozījumi prasības nodrošinājuma tiesiskajā regulējumā netika veikti, un pēdējā laikā neuzvirmo diskusijas par prasības nodrošinājuma piemērošanu. Taču tas nenozīmē, ka aktuālais prasības nodrošinājuma tiesiskais regulējums ir bez problēmām. Šajā rakstā tās tiek aktualizētas un analizētas.

Publikācijas tēmas aktualitāte izpaužas nepieciešamībā Civilprocesa likumā pilnveidot kritērijus gadījumos, kuros prasības nodrošinājuma pieteikums ir apmierināms vai noraidāms. Pašlaik Civilprocesa likumā un tiesu praksē ir izveidojušies pietiekami skaidri kritēriji, kā jāvērtē pirmškietamais (prima facie) formālais juridiskais pamatojums. Savukārt par prasības nodrošināšanas vērtēšanas kritērijiem gadījumos, kuros sprieduma izpilde bez prasības nodrošināšanas var kḷut apgrūtināta vai neiespējama, ne Civilprocesa likumā, ne tiesu praksē skaidrība nav rodama. Tādēl līdzīgos apstākḷos un ar līdzīgu motivāciju viens tiesnesis lūgumu par prasības nodrošinājumu apmierina, bet cits ne.

Juridiskajā literatūrā [14] un tiesu praksē [13] ir nostiprinājies uzskats, ka prasības nodrošināšana ir izṇēmuma līdzeklis, diemžēl skarbā dzīves realitāte ir atšḳirīga: tiesvedība vairāku gadu garumā bez prasības nodrošinājuma bieži vien ir bezjēdzīga, jo pēc tiesvedības pabeigšanas sprieduma izpilde parasti ir apgrūtināta vai neiespējama, lai gan prasības iesniegšanas brīdī parādnieka stāvoklis neliecināja par gaidāmām problēmām. İpaši tas attiecas uz juridiskām personām, kas bieži bankrotē (iesniedz maksātnespējas procesa pieteikumu tiesā) tad, kad tiek saṇemts tiesas spriedums, kas stājies spēkā.

Civilprocesa likuma nodaḷā par prasības nodrošinājumu vairākus gadus nav veikti grozijumi, turpretī citi tiesību akti, piemēram, Maksātnespējas likums, vairākkārt tikuši grozìti un attīstīti, svītrojot to trūkumus un pretrunas. Rezultātā ir izveidojusies situācija, ka prasības nodrošinājums neko nenodrošina, ja atbildētājs tiesvedības laikā ar tiesas nolēmumu kḷuvis maksātnespējīgs. Citas tiesvedības šajā gadījumā parasti tiek apturētas, pamatojoties uz Civilprocesa likuma 215. panta pirmās daḷas 6. punktu. Bet prasītājs, kura prasījuma tiesības ir apstiprinājis parādnieka maksātnespējas procesa administrators, neiegūst nekādas priekšrocības attiecībā pret citiem nenodrošinātiem kreditoriem, kaut arī, piemēram, zemesgrāmatā ir ierakstìta atzīme par ķīlas tiesību.

Nepieciešama padziḷināta izpēte, lai prasības nodrošinājuma institūtu padarìtu efektīvāku. Raksta tēma ir aktuāla arī no praktiskā viedokḷa, jo, apkopojot informāciju par problēmām, varēs uzlabot prasības nodrošinājuma pieteikumu vērtēšanas praksi, ierosinot pievērst īpašu uzmanību problemātiskajiem aspektiem un norādot virzienus, kuros nepieciešami plašāki pētījumi. 


\section{Darba mērķis, materiāls un metodes}

Publikācijas mērḳis ir aktualizēt problēmas un nepilnības aktuālajā prasības nodrošinājuma tiesiskajā regulējumā. Pētījuma materiāls ir tiesu prakse, judikatūra, normatīvie akti, t. sk. Civilprocesa likums un Maksātnespējas likums. Raksta izstrādē izmantota aprakstošā, analīzes un sintēzes metode, zinātniskās indukcijas un dedukcijas metode.

\section{Nepieciešamība pierādīt pamatota riska pastāvēšanu par prasītājam labvēlīga tiesas sprieduma izpildes iespējamu apgrūtinājumu vai pat neiespējamību}

Prasības nodrošināšana ir procesuāls aizsardzības līdzeklis, kuru nosaka tiesa vai tiesnesis pēc prasītāja motivēta pieteikuma gadījumā, ja ir pamats uzskatìt, ka tiesas sprieduma izpilde lietā varētu kḷūt apgrūtināta vai neiespējama [1]. Lemjot par prasības nodrošināšanu, tiek ṇemts vērā ne tikai prasības pirmšḳietami formālais juridiskais pamatojums, bet arī samērīgums starp pušu tiesiskajām interesēm [13].

Tātad, lai būtu pamats prasības nodrošināšanai, jāizpildās diviem priekšnosacijumiem:

1) prasībai pirmšķietami jābūt pamatotai un ticamai (kaut arī šajā posmā tiesa neveic pierādījumu pārbaudi);

2) jāpastāv pamatotam riskam, ka prasītājam labvēlīga tiesas sprieduma izpilde varētu būt apgrūtināta vai pat neiespējama.

Jāṇem vērā, ka prasītāja šaubas par sprieduma izpildes iespējamību, kas nav apstiprinātas ar konkrētiem pierādỉjumiem, nav uzskatāmas par pietiekamu pamatu pieteikuma par prasības nodrošināšanu apmierināšanai [13]. Tādējādi, ja prasītāja rīcībā nav pierādījumu, kas pamato šaubas, ka atbildētājs nevarēs izpildìt spriedumu, prasītāja apgalvojumi, ka atbildētājs nepilda savas saistības, nav pietiekami, lai nodrošinātu prasību. Prasītājam jāpierāda apstākḷi, kuru dēl sprieduma izpilde lietā varētu būt apgrūtināta vai neiespējama. Bieži vien šo apstākḷu pierādīšanai tiek izmantota informācija par sludinājuma ievietošanu interneta reklāmas vietnēs par atbildētājam piederošās mantas pārdošanu. Taču, lai tiesa varētu secināt, ka šì manta pieder tieši atbildētājam, papildus jāiesniedz arī informācija no publiskajiem reǵistriem (piemēram, no zemesgrāmatas, Uzṇēmumu regiistra, Ceļu satiksmes drošības departamenta u. c.). Praksē tas var radīt grūtības, jo dati par fiziskajai personai piederošo mantu tiek aizsargāti ar Fizisko personu datu apstrādes likuma normām un trešo personu piekḷūšana šādai informācijai ir ierobežota. Rezultātā par atbildētāju - fizisku personu vai jaunu juridisku personu - savākt informāciju, kas nepieciešama prasības nodrošinājuma pamatojuma pierādī̌anai, gandrīz nav iespējams.

Lai izvairītos no šādām situācijām, būtu ieteicams Civilprocesa likumā ieviest brīdinājuma kārtību, līdzīgu brīdinājumam par maksātnespējas procesa pieteikuma iesniegšanu tiesā, t. i., ja par parādnieku nav iespējams savākt nepieciešamo informāciju, izṇemot to, ka parādnieks ir dzīvs un nav izslēgts no iedzīvotāju regiistra, vai ieraksts par 
juridisku personu ir aktuāls, tad kreditors pirms prasības iesniegšanas tiesā, nosūtot ierakstìtu vēstuli ar satura atšifrējumu uz parādnieka juridisko vai deklarēto adresi, brīdina parādnieku, ka tiks sniegta prasība tiesā, ja noteiktajā termiņā saistības netiks izpildìtas vai netiks celti pamatoti iebildumi pret prasijumu, vai netiks sniegts saistïbu izpildes nodrošinājums vai pierādījumi, ka saistību izpilde nebūs apgrūtināta vai neiespējama. Ja atbilde uz brīdinājumu netiek sniegta vai tiek atzìta par nepamatotu, tas būs objektīvs pamats nodrošināt prasību.

Šādas brīdinājuma kārtības ieviešana atvieglos gan prasības nodrošinājuma nepieciešamības pierādīšanu gadījumos, kad par atbildētāju nav iespējams savākt vajadzīgo informāciju, gan atvieglos tiesu darbu, vērtējot prasības nodrošinājuma pieteikumu, jo tiks ievērots sacīkstes princips: atbildētājs ir sniedzis atbildi uz kreditora brīdinājumu, un tiesa atbildētāja iebildumus pret prasījumu var vērtēt jau prasības nodrošinājuma pieteikuma izskatī̌̌anas posmā. Šādas brīdinājuma kārtības ieviešana prasības nodrošinājuma institūtu padarīs efektīvāku, jo būs mazāk formālu tiesas atteikumu nodrošināt prasību un prasības tiks nodrošinātas visos gadijumos, kad tas ir objektīvi nepieciešams.

\section{Tiesas lēmuma par prasības nodrošinājumu pārsūdzēšana}

Atbilstoši Civilprocesa likuma 140. panta piektajai daḷai prasības nodrošinājumu pēc puses motivēta pieteikuma var atcelt tā pati tiesa, kura nodrošinājusi prasību, vai tiesa, kuras lietvedībā atrodas lieta izskatîšanai pēc būtības [1]. Savukārt atbilstoši Civilprocesa likuma 141. panta pirmajai dal̦ai tiek reglamentēts, ka par Civilprocesa likuma 140. panta trešajā daḷā minēto lēmumu, par lēmumu, ar kuru noraidìts pieteikums par prasības nodrošināšanu, un par lēmumu, ar kuru noraidìts pieteikums par prasības nodrošinājuma atcelšanu, kā arī par tiesas lēmumu par zaudējumu nodrošināšanu, kas atbildētājam varētu rasties saistībā ar prasības nodrošināšanu (140. panta otrā, $3 .^{1}$ un 5. ${ }^{1}$ dal̦a), var iesniegt blakus sūdzību [1].

Nav efektīvs regulējums, kurā atbildētājam ir tiesības iesniegt pieteikumu par prasības nodrošinājuma atcelšanu tai tiesai, kas pien̦ēma lēmumu par prasības nodrošinājumu, un, ja pieteikums ir noraidīts, tad iesniegt blakus sūdzību par to. Šāda kārtìba nesekmē procesuālo ekonomiju, jo ir izveidota divpakāpju pārsūdzēšanas sistēma, lai atceltu prasības nodrošinājumu, bet šo procesu var samazināt līdz vienai instancei, kura izskata blakus sūdzību par lēmumu, ar kuru prasība tika nodrošināta.

\section{Prasības nodrošinājuma summa}

Atbilstīgi Civilprocesa likuma 138. panta astotajai dal̦ai, apmierinot pieteikumu par prasības nodrošināšanu, tiesai lēmumā jānorāda summa, līdz kurai sniedzas nodrošinājums, taču tā nedrīkst būt lielāka par prasības summu. Savukārt atbilstīgi Civilprocesa 
likuma 35. panta pirmajai daḷai tiesāšanas un citi izdevumi prasības summā netiek iekḷauti, jo prasības summa ir:

- prasībās par naudas piedziṇu - piedzenamā summa;

- prasībās par mantas izprasīšanu - izprasāmās mantas vērtība;

- prasībās par uzturlīdzekḷ piedziṇu - maksājumu kopsumma par vienu gadu;

- prasībās par terminētiem maksājumiem un devumiem - visu maksājumu vai devumu kopsumma, bet ne vairāk kā par trim gadiem;

- prasībās par beztermiṇa vai mūža maksājumiem un devumiem - visu maksājumu un devumu kopsumma par trim gadiem;

- prasībās par maksājumu vai devumu samazināšanu vai palielināšanu - summa, par kuru samazina vai palielina maksājumus vai devumus, bet ne vairāk kā par vienu gadu;

- prasībās par maksājumu vai devumu izbeigšanu - atlikušo maksājumu vai devumu kopsumma, bet ne vairāk kā par vienu gadu;

- prasībās par nomas un īres līguma pirmstermiṇa izbeigšanu - maksājumu kopsumma par atlikušo līguma darbības laiku, bet ne vairāk kā par trim gadiem;

- prasībās par īpašumtiesībām uz nekustamo mantu - tās vērtība, bet ne mazāka par tās kadastrālo vērtību;

- prasībās, kas sastāv no vairākiem patstāvīgiem mantiskiem prasījumiem - visu prasijumu kopsumma;

- prasībās par darījuma izbeigšanu vai atzīšanu par spēkā neesošu - apstrīdētā darījuma summa.

Nav efektīvs pašreizējais regulējums, kurā paredzēts, ka, apmierinot pieteikumu par prasības nodrošināšanu, lēmumā norāda summu, līdz kurai sniedzas nodrošinājums, bet tā nedrīkst būt lielāka par prasības summu. Taču prasības summā nav iespējams norādìt likumiskos procentus no nodrošināmās prasības summas, valsts nodevu no nodrošināmās prasības un ar prasības nodrošināšanas lēmuma izpildi saistītos izdevumus - tas viss var liegt saṇemt likumiskos sešus procentus gadā no nesamaksātās parāda summas par laiku līdz sprieduma izpildei -, kā arī līgumsodu, tiesāšanās izdevumus, ar tiesas sprieduma izpildi saistìtos izdevumus, izdevumus par lēmuma par prasības nodrošināšanu nostiprināšanu zemesgrāmatā un ar prasības nodrošināšanas lēmuma izpildi saistītos izdevumus.

Turklāt šāds regulējums aizskar prasītāja Satversmes 92. panta pirmajā un otrajā teikumā ietvertās tiesības ("Ikviens var aizstāvēt savas tiesības un likumiskās intereses taisnīgā tiesā. Nepamatota tiesību aizskāruma gadījumā ikvienam ir tiesības uz atbilstīgu atlīdzinājumu.") un 105. panta pirmajos trīs teikumos ("Ikvienam ir tiesības uz ìpašumu. İpašumu nedrīkst izmantot pretēji sabiedrības interesēm. İpašuma tiesības var ierobežot vienīgi saskaṇā ar likumu.") noteiktās pamattiesības, kā arī šis regulējums neatbilst Satversmes 91. panta pirmajā teikumā ietvertajam vienlīdzības principam, jo nesamērīgi ierobežo prasītāja tiesības iekḷaut prasības nodrošinājuma summā arī izdevumus, kas saistîti ar prasības celšanu. [3] 


\section{Prasības nodrošinājuma atcelšana maksātnespējas procesā}

Maksātnespējas likuma 63. panta piektajā daḷā ir noteikts, ka tiesas spriedums, ar kuru tiek pasludināts juridiskās personas maksātnespējas process, ir pamats prasības nodrošinājuma atcelšanai Civilprocesa likumā noteiktajā kārtībā [4]. Atbilstīgi Maksātnespējas likuma 134. panta piektajai daḷai tiesas spriedums, ar kuru tiek pasludināts fiziskās personas maksātnespējas process, ir pamats prasības nodrošinājuma atcelšanai Civilprocesa likumā noteiktajā kārtībā.

Arī judikatūrā ir nostiprinājusies atziṇa, ka kreditors, kuram par labu tiesa nodrošinājusi prasību, nekḷūst par nodrošināto kreditoru Maksātnespējas likuma izpratnē un nebauda nekādas priekšrocības pār citiem kreditoriem. Prasības nodrošinājums nekādā veidā neietekmē sprieduma izpildes iespējamību, jo tā ir atkarīga no kopējā kreditoru skaita un saistību apjoma, nevis no prasības nodrošinājuma esamības vai neesamības [9].

Šìs atziñas un Maksātnespējas likuma normas (par pamatu atcelt prasības nodrošinājumu, ja ir pasludināts juridiskās vai fiziskās personas maksātnespējas process) ir pārāk kategoriski noformulētas un ir pretrunā ar Maksātnespējas likuma 6. panta pirmās daḷas 1. un 2. punktā noteiktajiem maksātnespējas procesa principiem. Piemēram, tās neatbilst tiesību saglabāšanas principam - maksātnespējas procesā tiek ievērotas pirms maksātnespējas procesa iegūtās kreditoru tiesības; savukārt kreditora tiesību ierobežojums, kas noteikts maksātnespējas procesā, nevar būt lielāks, nekā ir nepieciešams attiecīgā procesa mērḳa sasniegšanai un kreditoru vienlīdzības principam - kreditoriem tiek dotas vienādas iespējas piedalīties procesā un saṇemt savu prasījumu apmierinājumu saskaṇā ar saistībām, kuras tie nodibinājuši ar parādnieku pirms procesa uzsākšanas.

Šis Maksātnespējas likuma tiesību normas kategoriskums izraisa prasības nodrošinājuma atcelšanu, nevērtējot Civilprocesa likumā noteiktajā kārtībā prasības atcelšanai paredzētus faktiskus un juridiskus apstākḷus, vien aprobežojoties ar formālu motivāciju, ka "nav nozīmes prasītāja pārstāvja argumentiem, ka administratore nepamatoja, kā prasības nodrošinājums var traucēt administratorei pildīt pienākumu nodrošināt efektīvu un likumīgu maksātnespējas procesu, jo tiesa atzīst, ka administratorei bez kāda nepieciešamības papildu pamatojuma, balstoties tikai uz Maksātnespējas likuma 63. panta piekto dal̦u, ir pamats prasīt nodrošinājuma atcelšanu" [5].

Neapšaubāmi, daži prasības nodrošinājuma līdzekḷi (piemēram, parādnieka kustamās mantas un skaidras naudas līdzekḷu apḳ̂ilāšana u. c.) maksātnespējas procesa administratoram var traucēt parādnieka mantas pārņemšanu un izpildīt citus Maksātnespējas likumā noteiktos pienākumus, kas saistīti ar parādnieka mantas pārdošanu. Bet ne visi līdzekḷi traucēe piemēram, ḳilas tiesības atzīmes ierakstī̌̌ana zemesgrāmatā uz parādnieka nekustamo īpašumu nevar traucēt maksātnespējas administratoram pildīt savus pienākumus, kas saistīti ar parādnieka nekustamā īpašuma pārdošanu, jo, pārdodot mantu izsolē un apstiprinot izsoles aktu, saskaṇā ar Civilprocesa likuma 617. panta piekto daḷu ar tiesas lēmumu dzēšami arī piemērotie prasības nodrošinājumi. 
Tādēḷ prasības nodrošinājuma bezierunu atcelšana, ja ir pasludināts juridiskās vai fiziskās personas maksātnespējas process, neatbilst Maksātnespējas likumā noteiktajam tiesību saglabāšanas principam - maksātnespējas procesā tiek ievērotas pirms maksātnespējas procesa iegūtās kreditoru tiesības. Kreditora tiesību ierobežojums, kas noteikts maksātnespējas procesā, nevar būt lielāks, kā vajadzịgs procesa mērḳa sasniegšanai, tādēl būtu nepieciešams kreditoram ar prasības nodrošinājumu piešḳirt nodrošinātā kreditora statusu, ja šāda kreditora prasījums ir apstiprināts maksātnespējas procesā, ja nav strīda par tiesībām un prasības nodrošinājuma līdzeklis netraucē maksātnespējas procesa administratoram veikt Maksātnespējas likumā paredzētos pienākumus, kas saistīti ar parādnieka mantas pārṇemšanu un pārdošanu.

\section{Secinājumi un priekšlikumi}

1. Lai nepieļautu formālu tiesas atteikumu nodrošināt prasību, jāizskata iespēja Civilprocesa likumā ieviest brīdinājuma kārtìbu, kas būtu līdzīga brīdinājumam par maksātnespējas procesa pieteikuma iesniegšanu tiesā, t. i., ja par parādnieku nav iespējams savākt vairāk informācijas, izṇemot to, ka parādnieks ir dzīvs un nav izslēgts no iedzìvotāju registra, vai ieraksts par juridisku personu ir aktuāls, tad kreditors pirms prasības iesniegšanas tiesā, nosūtot ierakstîtu vēstuli ar satura atšifrējumu uz parādnieka juridisko vai deklarēto adresi, brīdina parādnieku, ka tiks sniegta prasība tiesā, ja noteiktajā termin,ā saistības netiks izpildītas vai netiks celti pamatoti iebildumi pret prasijumu, vai netiks sniegts saistïbu izpildes nodrošinājums vai pierādỉjumi, ka saistību izpilde nebūs apgrūtināta vai neiespējama. Ja atbilde uz brīdinājumu netiks sniegta vai tiks atzìta par nepamatotu, tas būs objektīvs pamats nodrošināt prasību. Šādas brīdinājuma kārtības ieviešana atvieglos gan prasības nodrošinājuma nepieciešamības pierādišanu gadījumos, kuros par atbildētāju nav iespējams savākt nepieciešamo informāciju, gan atvieglos arī tiesas darbu, vērtējot prasības nodrošinājuma pieteikumu, jo tiks ievērots sacīkstes princips: atbildētājs ir sniedzis atbildi uz kreditora brīdinājumu un tiesa atbildētāja iebildumus pret prasījumu var vērtēt jau prasības nodrošinājuma pieteikuma izskatīšanas posmā.

2. Nav efektīvs Civilprocesa likuma regulējums, ka atbildētājam ir tiesības iesniegt pieteikumu par prasības nodrošinājuma atcelšanu tai tiesai, kas pieñēma lēmumu par prasības nodrošinājumu, un, ja pieteikums ir noraidìts, tad ir iesniedzama blakus sūdzỉba par to. Šis regulējums nesekmē procesuālo ekonomiju, jo ir izveidota pārsūdzēšanas divpakāpju sistēma, lai atceltu prasības nodrošinājumu, taču šo procesu var samazināt līdz vienai tiesu instancei, kura izskata blakus sūdzỉbu par lēmumu, ar kuru prasība tika nodrošināta.

3. Nav efektīvs pašreizējais tiesiskais regulējums, kurā paredzēts, ka, apmierinot pieteikumu par prasības nodrošināšanu, lēmumā norāda summu, līdz kurai sniedzas nodrošinājums, taču tā nedrīkst būt lielāka par prasības summu, tādēl 
šādi tiek nesamērīgi ierobežotas prasītāja tiesības iekḷaut prasības nodrošinājuma summā arī izdevumus, kas saistīti ar prasības celšanu.

4. Prasības nodrošinājuma bezierunu atcelšana, ja ir pasludināts juridiskās vai fiziskās personas maksātnespējas process, neatbilst Maksātnespējas likumā noteiktajam tiesību saglabāšanas principam - maksātnespējas procesā tiek ievērotas pirms maksātnespējas procesa iegūtās kreditoru tiesības -, tādēl pašreizējo tiesisko regulējumu būtu jāpapildina ar iespēju kreditoram ar prasības nodrošinājumu pieškirt nodrošinātā kreditora statusu, ja šāda kreditora prasījums ir apstiprināts maksātnespējas procesā, nav strīda par tiesībām un prasības nodrošinājuma līdzeklis netraucē maksātnespējas procesa administratoram veikt Maksātnespējas likumā paredzētos pienākumus, kas saistīi ar parādnieka mantas pārṇemšanu un pārdošanu.

\section{Problems of Securing a Claim}

\section{Abstract}

The article researches the problems of the legal framework for securing a claim, because important improvements for the legal framework for securing a claim have not been made in recent years, making this law institute less effective. This article updates the problems related to the legal framework for securing a claim and its application, which can help to initiate discussions to resolve them and to promote the economy of the civil procedure, exposure and effectiveness for securing a claim.

Keywords: securing a claim, civil procedure, insolvency process, procedural economy.

\section{Avoti un literatūra}

\section{Tiesību akti}

1. Civilprocesa likums: Latvijas Republikas likums: pieṇemts 14.10.1998., stājās spēkā 01.03.1999. Latvijas Vèstnesis. 326/330(1387/1391), 03.11.1998. Iegūts no: https://likumi.lv/doc.php?id=50500 [sk. 01.03.2019.].

2. Fizisko personu datu apstrādes likums: Latvijas Republikas likums: pieñemts 21.06.2018., stājās spēkā 05.07.2018. Latvijas Vēstnesis. 132(6218), 04.07.2018. Iegūts no: https://likumi.lv/ ta/id/300099-fizisko-personu-datu-apstrades-likums [sk. 01.03.2019.].

3. Latvijas Republikas Satversme: Latvijas valsts likums: pieṇemts 15.02.1922., stājās spēkā 07.11.1922. Latvijas Vëstnesis. 43, 01.07.1993. Iegüts no: https://likumi.lv/doc.php? mode=DOC\&id=57980 [sk. 01.03.2019.].

4. Maksātnespējas likums: Latvijas Republikas likums: pieṇemts 26.07.2010., stājās spēkā 01.11.2010. Latvijas Vēstnesis. 124(316), 06.08.2010. Iegūts no: https://likumi.lv/doc.php?id=214590 [sk. 01.03.2019.]. 


\section{Tiesu prakse}

5. Daugavpils tiesas lēmums 01.11.2018. lietā Nr. C33434117.

6. Latvijas Republikas Augstākās tiesas Civillietu departamenta 2014. gada 29. decembra lēmums lietā Nr. SKC-3133/2014. Iegūts no: http://www.at.gov.lv/lv/judikatura/judikaturas-nolemumuarhivs/civillietu-departaments/hronologiska-seciba?year=2014. [sk. 01.03.2019.].

7. Latvijas Republikas Augstākās tiesas Civillietu departamenta 2017. gada 12. janvāra spriedums lietā Nr. C37105312 SKC-5/2017. Iegūts no: http://www.at.gov.lv/lv/judikatura/judikaturas-nolemumu-arhivs/civillietu-departaments/hronologiska-seciba?year=2017 [sk. 01.03.2019.]

8. Latvijas Republikas Augstākās tiesas Civillietu departamenta 2017. gada 17. oktobra lēmums lietā Nr. C30316415, SKC-1587/2017. Iegūts no: http://www.at.gov.lv/lv/judikatura/judikaturasnolemumu-arhivs/civillietu-departaments/hronologiska-seciba?year=2017 [sk. 01.03.2019.].

9. Latvijas Republikas Augstākās tiesas Senāta Civillietu departamenta 2011. gada 6. aprīḷa lēmums lietā Nr. SKC-951/2011. Iegūts no: at.gov.lv/downloadlawfile/3158 [sk. 01.03.2019.].

10. Latvijas Republikas Augstākās tiesas Senāta Civillietu departamenta 2012. gada 20. jūnija lēmums lietā Nr. SKC-1644/2012. Iegūts no: http://www.at.gov.lv/lv/judikatura/judikaturas-nolemumuarhivs/civillietu-departaments/hronologiska-seciba?year=2012 [sk. 01.03.2019.].

11. Latvijas Republikas Augstākās tiesas Senāta Civillietu departamenta 2013. gada 24. aprīḷa lēmums lietā Nr. SKC-1654/2013. Iegūts no: http://www.at.gov.lv/lv/judikatura/judikaturas-nolemumuarhivs/civillietu-departaments/hronologiska-seciba?year=2013 [sk. 01.03.2019.].

12. Latvijas Republikas Augstākās tiesas Senāta Civillietu departamenta 2013. gada 4. decembra lēmums lietā Nr. SKC-2021/2013. Iegūts no: http://www.at.gov.lv/lv/judikatura/judikaturasnolemumu-arhivs/civillietu-departaments/hronologiska-seciba?year=2013 [sk. 01.03.2019.].

13. Tiesu prakse prasības nodrošināšanas lietās. 2015. Latvijas Republikas Augstākā tiesa: Senāts. Iegūts no: http://www.at.gov.lv/lv/judikatura/tiesu-prakses-apkopojumi/civiltiesibas [sk. 01.03.2019.].

\section{Literatūra}

14. Civilprocesa likuma komentāri. 2016. I daḷa. Aut. kol. prof. K. Torgāna zin. vad. Rīga: TNA. 